DOI: $10.5507 /$ sth.2019.044

\title{
Immensum $\mathbf{v}$ kontextu Leibnizovy korespondence s Clarkem*
}

Kateřina Lochmanová

Jak se domnívá Grant, Leibniz byl mezi prvními, kdo se v novověku pokusili oddělit prostor od Boha, a osvobodit tak diskusi ohledně prostoru od otázek teologických. ${ }^{1}$ Sloučení Boha s prostorem, jak jej provedli Henry More či Isaac Newton, by totiž, přidává se Hartz, mělo katastrofické důsledky. ${ }^{2}$ Vzhledem $\mathrm{k}$ tomu, že zkrátka žádná stvořená monáda není od prostoru izolována do takové míry, do jaké je od něj izolován samotný Bůh, ${ }^{3}$ nemohlo podle nich označení prostoru za nekonečný v rámci Leibnizova systému nijak souviset $\mathrm{s}$ Bohem. ${ }^{4}$ Na rozdíl od Clarka, pro nějž byl prostor přímo Boží vlastností, tak pro Leibnize podle jejich soudu představoval pouhý souhrn relací či pouhé ens rationis, podobně jako je tomu v případě matematických záležitostí obecně. ${ }^{5}$

Zatímco se tedy Leibniz údajně spokojil s (dle Vailatiho tradičním) pojetím Boha coby substanciálně vyčleněného z prostoru i času, Clarke to považoval za přinejmenším nenahlédnutelné a přinejhorším zcela

* Tato studie byla zpracována v rámci řešení projektu SGS03/FF/2019-2020: Bílá místa dějin a současnosti filozofie: Osobnosti a témata na okraji kánonu.

1 Edward Grant, Much Ado About Nothing: Theories of Space and Vacuum from the Middle Ages to the Scientific Revolution, Cambridge: Cambridge University Press, 1981, s. 261-264.

2 Glenn Hartz, Leibniz's Final System: Monads, Matter and Animals, London: Routledge, 2007, s. 61.

3 Norman Fenton, A New Interpretation of Leibniz's Philosophy: With Emphasis on His Theory of Space, Dallas: Paon Press, 1973, s. 150. Srov. též Leonardo Ruiz Gómez, El concepto leibniziano de espacio: La polémica noc Clarke y el newtonianismo, Pamplona: Ediciones universidad de Navarra, 2014, s. 403.

4 Grant, Much Ado About Nothing, s. 262.

5 Ezio Vailati, Leibniz and Clarke: A Study of Their Correspondence, New York: Oxford University Press, 1997, s. 109; Nicholas Jolley, „Plenitude and Mirrors of God in Leibniz," in Tercentery Essays on the Philosophy and Science of Leibniz, ed. Lloyd Strickland - Erik Vynckier - Julia Weckend, Cham: Springer International Publishing, 2017, s. 111-129, s. 116. 
rozporné. ${ }^{6}$ Clarkovy teologické zájmy mu zkrátka nedovolovaly, aby se $\mathrm{v}$ rámci korespondence $\mathrm{s}$ Leibnizem po vzoru Newtona omezil na čistě fyzikální problémy.7 Snad právě proto přisuzují někteří podobně deteologizující záměry dokonce i Newtonovi, např́klad Stein, jenž coby usvědčující důkaz ${ }^{8}$ uvádí Newtonovo tvrzení, že absolutní ideou rozprostraněnosti disponujeme bez jakéhokoliv vztahu $\mathrm{k}$ Bohu, pročež jsme uschopněni navzdory uznání její existence předstírat neexistenci Boží. ${ }^{9}$ Úplné prvenství, dodávají, však v tomto ohledu náleželo už Descartovi, ${ }^{10}$ nebot právě on byl podle mnohých tím, kdo jako první oddělil látku od ducha. ${ }^{11} \mathrm{~A}$ právě důkazu naprosté pomýlenosti této (textové evidenci odporující) interpretace bude celá tato studie zasvěcena.

Za vůbec prvního, kdo $\mathrm{v}$ novověku neodvolatelně rozlomil pouto rozprostraněnosti a ducha, by přitom s jistými výhradami zřejmě skutečně bylo možno označit právě Descarta, ${ }^{12}$ jehož dualistická bifurkace (Whiteheadův pojem $)^{13}$ byla natolik hluboká, že se následkem toho prostor posléze stal duchovnímu světu pouhou poněkud nežádoucí metafyzikou - čímsi, bez čeho se obejde a vůči čemu nepotřebuje udržovat žádný vztah vůbec. Descartovým současníkům však - a to je zapotřebí zdůraznit - bylo takové pojetí ještě poněkud cizí, nebot’ se stále ještě cítili povinni tvrdit, že prostor je přeci jen v jistém ohledu vlastností Boží, Bohem samotným nebo s ním alespoň podstatným zpưsobem souvisí. ${ }^{14}$ Vždyṫ už Henry More Descartovi svého času namítal, že dokonce i Bůh

6 Vailati, Leibniz and Clarke, s. 19.

7 Leroy Loemker, "Introduction: Leibniz as Philosopher," in Philosophical Papers and Letters, překl. Leroy Loemker, Chicago: University of Chicago Press, 1956, s. 1-62, s. 32.

8 Howard Stern, "Newton's Metaphysics," in The Cambridge Companion to Newton, ed. Bernard Cohen - George Smith, Cambridge: Cambridge University Press, 2002, s. 271.

9 De gravitatione (IsaAc Newton, U 109;143).

10 Hartz, Leibniz's Final System, s. 61.

11 Tamtéž, s. 62.

12 I v Descartově př́ípadě se ovšem jednalo spíše o pouhou eskalaci dlouhodobějšího trendu nežli o jakkoliv ostrý přelom. Zatímco tak ještě scholastikové věřili, že čísla vyvstávají výhradně na základě dělení kontinua, a dávali tudíž přednost kvalitám (Characteristica geometrica; GotTfRIEd Wilhelm LeIBNiz, GP IV,35,\$6), nejpozději počínaje Galileem už začaly být kvality omezovány čistě na sféru vědomí, takže fyzikálnímu světu nadále přináležely už jen časoprostorové vlastnosti (HARTz, Leibniz's Final System, s. 32n.).

13 Srov. Alfred North Whitehead, The Concept of Nature, Cambridge: Cambridge University Press, 2015, kap. 2.

14 Hartz, Leibniz's Final System, s. 62. 
sám je svým způsobem rozprostraněný a rozprostřený15 a ani tím, vůči komu se svým argumentem ohledně idey rozprostraněnosti vymezoval Newton, nebyl nikdo jiný než právě Descartes.

Newton sám totiž považoval zakomponování teologických myšlenek do své teorie prostoru za vyloženě nezbytné a výhodné. ${ }^{16}$ Právě narůstající zájem o teologické a spirituální otázky $\mathrm{v}$ průběhu jeho pozdních let byl ostatně zřejmě jedním z hlavních motivů $\mathrm{k}$ sepsání inkriminovaného Scholia. Dalším z motivů pak mohl být př́mo Cotesův požadavek, aby zabránil opětovnému nařčení $\mathrm{z} \mathrm{k}$ ateismu, ${ }^{17}$ jaký přitom Newton sám v rámci De gravitatione vytýkal naopak Descartovi. Jednalo se totiž o Descartův pojem rozprostraněnosti identické s tělesem, jejž Newton touto cestou napadal: "Tvrdíme-li spolu s Descartem," uvedl tamtéž, „že rozprostraněnost je tělesem, neprostíráme očividně cestu $k$ ateismu (...)? ${ }^{\prime 18}$ Ostatně celé De gravitatione není ničím než rozvinutou sérií protiargumentů proti karteziánské př́rodní filosofii, ${ }^{19}$ na což posléze navázali rovněž další z Newtonových příznivců. Za vůbec nejhorlivějšího z do-

15 Dopis od Mora Descartovi (René Descartes, MD X,181). Descartes odvětil, že Bůh je sice vskutku rozprostraněný co do své síly, nebot' je schopen pohybovat hmotou v libovolném bodě, přesto je však od přesné geometrické rozprostraněnosti přisouditelné hmotě esenciálně odlišný (Dopis Morovi; René Descartes, MD X,195-197).

16 Max Jammer, Concepts of Space: The History of Theories of Space in Physics, Cambridge: Harvard University Press, 1970, s. 2.

17 Tamtéž, s. 112.

18 „Si cum Cartesio dicamus extensionem esse corpus, an non Atheiae viam manifeste sternimus (...)" (De gravitatione; IsaAc Newton, U 109,142n.). Neméně kritický byl $\mathrm{v}$ tomto ohledu vưči Descartovi rovněž Leibniz (Dopis Basnagovi z roku 1693; GotTfried Wilhelm Leibniz, GP III,97; Autres argumens de M. Jaquelot; GotTfried Wilhelm Leibniz, GP III,453,§g; Dopis de Volderovi; Gottfried Wilhelm Leibniz, LDV,108). Až do roku 1672 přitom bylo i Leibnizovo vlastní pojetí rozprostraněnosti zatím ještě vesměs karteziánské, nebot ji považoval za jednoduchý, tj. dále neanalyzovatelný atribut tělesa (Dennis Joseph Martin, Leibniz's Conception of Analysis Situs and Its Relevance to the Problem of the Relationship between Mathematics and Philosophy, Ann Arbor, Michigan: University Microfilms International, 1985, s. 142), což se od něj dozvídáme ještě i roku 1676: „Rozprostraněnost je čímsi převelice jednoduchým." [,Extensio est aliquid simplicissimum" (Cogitatio non est motus; GotTrried Wilhelm Leibniz, DSR 110)]. Nejpozději roku 1691 už však dospěl k závěru, že těleso neboli látka se od pouhé rozprostraněnosti zásadně odlišuje. [„,...) Corps ou (...) la matiere est autre que celle (...) l'étendue" (Bez názvu; Gottfried Wilhelm Leibniz, GP IV,464)].

19 Andrew Janiak, „Introduction," in Philosophical Writings, Cambridge: Cambridge University Press, 2004, s. XVIII; Geoffrey Gorham, „Newton on God's Relation to Space and Time: The Cartesian Framework," Archiv für Geschichte der Philosophie 93, č. 3 [298] (2011): 280-320. 
bových obhájců prostoru coby Božího atributu pak lze mezi newtonovci považovat Josepha Raphsona. ${ }^{20}$

Jistě, že jen o několik desetiletí později už se podobné pokusy o propojení kosmologie s teologií začaly jevit poněkud staromódně, ${ }^{21}$ tím ovšem nijak nelze zastř́t skutečnost, že nejen pro Newtona, ale také pro Clarka, jakož i pro Leibnize byl ještě Bůh dokonce tím vůbec nejdůležitějším komponentem jejich metafyziky prostoru. Zatímco by totiž ohledně Descarta snad skutečně bylo možno potvrdit, že pro něj Bůh neměl s prostorem de facto vůbec nic společného (až na to, že je jeho stvořitelem ${ }^{22} \mathrm{a}$, dodejme, také udržovatelem), pro Leibnize, stejně jako pro Newtona, by něco takového bylo naprosto nemyslitelné. Vždyt̉ právě Bůh byl pro ně garantem reálné existence prostoru: tím, co je na prostoru reálného (Leibniz to nazýval immensum či expansum), totiž není nic jiného nežli Bůh samotný pojatý jakožto všudypř́tomný (quatenus cogitatur ens ubique). ${ }^{23}$

\section{LeIBNIZ A IMMENSUM}

Tím, na čem se podle Hartze a Covera shodují takřka veškeré tradiční interpretace Leibnizovy metafyziky prostoru, je předpoklad, že se jedná o nanejvýš dvouúrovňové metafyzické schéma, ${ }^{24}$ sestávající typicky $\mathrm{z}$ říše monád, tj. $\mathrm{z}$ metafyziky, a dále z předmětů každodenní zkušenosti, jimiž se zabývají vědy obecně, zejména pak fyzika. ${ }^{25}$ Vzhledem $\mathrm{k}$ tomu, že jsou navíc fyzikální tělesa v Leibnizově pojetí obvykle považována za pouhé fenomény, funkce učinit tělesa alespoň opodstatněnými, bývá, dodejme, $\mathrm{v}$ takovém př́padě vyhrazena právě monádám. $Z$ prostoru, jenž je zcela identický s tělesy, se tak na základě toho stává pouhý opodstatněný fenomén. Jen poměrně malé množství leibnizovských badatelů

20 Vincenzo De Risi, Geometry and Monadology: Leibniz's Analysis Situs and Philosophy of Space, Berlín: Birkhäuser, 2007, s. 564, pozn. 86.

21 Bertoloni Domenico Meli, Equivalence and Priority: Newton versus Leibniz, Oxford: Clarendon Press, 1993, s. 191.

22 Hartz, Leibniz's Final System, s. 62.

23 De Risi, Geometry and Monadology, s. 56. Srov. De origine rerum ex formis (GotTrRied WilHeLM LeIBNIZ, DRS 78n.).

24 Glenn Hartz - Jan Cover, „,Space and Time in the Leibnizian Metaphysics, “ Nous, č. 22 [494] (1988): 493-519.

25 Nicholas Rescher, Leibniz: An Introduction to His Philosophy, Totowa: Rowman and Littlefield, 1979, s. 65. 
přitom podle Anapolitana uznává, že je zapotřebí rozlišovat nikoliv úroveň dvojí, nýbrž rovnou trojí. ${ }^{26}$ Jinými slovy: jak se v rámci této studie pokusím prokázat, monády samotné zdaleka nebyly tím jediným, co lze na Leibnizově jinak čistě fenomenálním prostoru považovat za reálné.

Leibniz totiž kromě monád a rozprostraněnosti coby pouhého fenoménu dělitelného na jednotlivé části rozlišoval ještě rozprostraněnost o sobě (per se) neboli immensitu, rovněž nekonečnou, avšak nedělitelnou a věčnou. Immensita zkrátka podle něj odpovídá věčnosti, a jelikož ani věčnost per se nenazýváme sukcesí, ani rozprostraněnost per se neboli immensitu nenazýváme rozprostraněností obdařenou částmi. ${ }^{27}$ Dokonce i části fenomenálního prostoru jsou navíc navzdory jeho nekonečnosti stále ještě spočetné, a tudíž měřitelné. Oproti tomu rozprostraněné per se však odpovídá Leibnizově interpretaci Spinozova pojetí Boha coby nekonečné, věčné a především nezměrné ${ }^{8}$ substance, jejíž atributy tuto nekonečnou a věčnou (tj. nesmírnou) substanci vyjadřují. ${ }^{29}$

$\mathrm{V}$ prostoru se zkrátka podle Leibnize musí nacházet cosi neměnného a věčného, totiž immensita Boží, jejímž je prostor až důsledkem coby vlastnost určité esence, ${ }^{30}$ podobně jako je tomu i v př́padě vědomí,

26 Dionysios Anapolitanos, Leibniz: Representation, Continuity and the Spatiotemporal, Dodrecht: Kluwer Academic Publishers, 1999, s. 94.

27 De magnitudine (GotTfried Wilhelm Leibniz, DSR 42n.).

28 Pojem immensitas, respektive immensus, sice bývá překládán ve smyslu rozsáhlý, pro Leibnize však Bůh nebyl ani tak rozsáhlým, jako spiše neměřitelným, pročež je mu immensita rovněž synonymem nekonečnosti (George Henry Radcliffe PARKInson, „Notes," in De Summa Rerum: Metaphysical Papers 1675-1676, New Haven: Yale University Press, 1992, s. 122, pozn. 92). Jedná se ovšem podle Leibnize o jiný typ nekonečného než neohraničené (De arcanis sublimum; GotTFRIEd WilHelm Leibniz, DSR 26n.). A právě pro tento dvojí aspekt immensity, totiž nezměrnost spolu s nekonečností, ji budu nadále překládat pojmem nesmírnost: „,(...) Abychom jej totiž odlišili od prostoru, bude nejlepším nazývat jej nesmírným.“ [„,(...) Itaque, ut hoc ut a spatio distinguam, vocem ipsum Immensum" (De origine rerum ex formis; GotTfried WiLHeLm LeIbNiz, DSR 76n.)]. Správně je tedy ono nekonečné nazýváno nesmírným (De arcanis sublimum; GotTrRIED Wilhelm LeibNiz, DSR 26n.), přičemž právě toto nesmírné je tím, co přetrvává; není, a ani nemůže být ohraničené, je jediné a nedělitelné, pročež je rovněž možno nazývat jej rozprostřeným [expanded] (De origine rerum ex formis; GotTrRied Wilhelm Leibniz, DSR 76n.).

Communicata ex literis Domini Schulleri (GotTfried Wilhelm Leibniz, LoC 102n.).

Notizen zur Wissenschaft und Metaphysik (Gottrried Wilhelm Leibniz, A VI,3,391). A právě to „(...) patrně nahlíželi ti, kteří věřili, že Bůh sám se nachází v látce těles.“ ["(...) Quod illi intellexisse videntur, qui Deum ipsum esse credidere materiam rerum" (Notizen zur Wissenschaft und Metaphysik; Gottrried Wilhelm Leibniz, A VI,3,392)]. 
jež se totiž rovněž neustále kontinuálně proměňuje, ${ }^{31}$ nikoli však jeho božská část, jíž Aristotelés přezdíval aktivní rozum. ${ }^{32} \mathrm{~V}$ tomto ohledu Leibniz překonal dokonce i samotného Newtona, pakliže kromě vlastností neměnnosti, kontinuity a nekonečnosti, jaké prostoru přisuzoval už Newton, doplnil ještě předpoklad, že naše mysli participují na části Boží inteligence ve stejném smyslu, $\mathrm{v}$ jakém naše bytosti zaujímají část nekonečného prostoru. ${ }^{33}$ Právě tímto způsobem tedy vzniká prostor i jednotlivá místa $v$ něm, jejichž agregáty dávají vzniknout prostoru fenomenálnímu, podobně jako je společenství myslí agregátem myslí individuálních, přičemž Boží mysl se má k naší asi jako immensum čili reálný prostor $\mathrm{k}$ prostoru fenomenálnímu. ${ }^{34}$ Boží esence tak zapřičiňuje prostor, v němž následně veškerá tělesa existují, ${ }^{35} \mathrm{~s}$ tím, že prostor samotný lze $\mathrm{z}$ tohoto řádu jednotlivin zpětně vyabstrahovat opět prostřednictvím mysli. ${ }^{36}$ Za podklad či bázi prostoru nadto Leibniz považoval právě immensum, a nikoliv prostor jevící se smyslům. ${ }^{37}$

V Bohu je však nutně př́tomna nejen idea nekonečné absolutní rozprostraněnosti (immensity), ale rovněž libovolného tvaru, jenž totiž pro tuto absolutní rozprostraněnost není ničím než modifikací. Ostatně dokonce i při vjemu barev či pachů jsou ve skutečnosti vnímány pouze

31 De formis simplicibus (GotTfried Wilhelm Leibniz, DSR 82n.).

32 Notizen zur Wissenschaft und Metaphysik (GotTrried Wilhelm Leibniz, A VI,3,391,I,\$20nn.); De origine rerum ex formis (GotTfried Wilhelm Leibniz, DRS 78n.). Ohledně vztahu mezi Bohem a rozumem u Aristotela srov. Filip Svoвoda, „Problematika limit vědeckého poznání v Aristotelově ,hledané vědě se speciálním zaměřením na první a druhou kapitolu knihy $A$ a s přihlédnutím ke spisům Organonu," in Limity vědeckého poznání, ed. Martin Škabraha, Ostrava: Ostravská univerzita, 2013, s. 24n., pozn. 26n., s. 30n., pozn. 48-50, s. 33, pozn. 56. Gómez, El concepto leibniziano de espacio, s. 310.

34 De origine rerum ex formis (GotTfRIed Wilhelm LeibNiz, DSR 76n.). Jediným rozdílem mezi agregátem myslí a agregátem prostoru je ten, že mysl přetrvává, zatímco místa se kontinuálně proměňují v souvislosti s pohybem látky. Kontinuálně tedy vznikají a zase zanikají (Gottfried Wilhelm LeIBNiz, DSR 80). Dř́ive Leibniz přirovnával mysl dokonce k atomu: „Stav duše, podobně jako atomu, je stavem změny, tendencí. Atom má tendenci měnit místo, duše měnit myšlenky; jeden i druhý se sám o sobě mění tím nejjednodušším a nejuniformějším způsobem, jaký jen jeho stav umožňuje.“ [,"L'estat de l'ame, comme de l'atome, est un estat de changement, une tendance: l'atome tend à changer de lieu, l'ame à changer de pensée; l'un et l'autre de soy change de la maniere la plus simple et la plus uniforme, que son estat permet" (Response aux reflexions contenues; GotTfried Wilhelm Leibniz, GP IV,562)].

De origine rerum ex formis (GottrRied Wilhelm Leibniz, DSR 76n.). 
př́slušné tvary a pohyby, ty jsou však, na rozdíl od rozprostraněných těles, natolik rozmanité a nepatrné, že je mysl nedokáže zřetelně rozlišit. ${ }^{38}$ Útvary jsou zkrátka modifikací rozprostraněnosti podobně, jako jsou sekundární síly modifikací monád. ${ }^{39}$ Vzmach (nisus, tj. elementární jednotka pohybu) tedy není o nic méně modifikací formy než je útvar sám modifikací látky. ${ }^{40} \mathrm{~A}$ jako se útvar již nachází $\mathrm{v}$ immensu ještě předtím, než je $\mathrm{v}$ něm vůbec vyznačen, tak se také idea čili myšlenkový rozdíl již nachází v prvotní inteligenci. Jako se navíc posléze útvar vyskytne rovněž v prostoru, tak se zajisté posléze také idea vyskytne v mysli lidské. ${ }^{41}$

Původně přitom Leibniz tvrdil, že za predpokladu, že by se prostor skládal z částí, tedy že by byl zaplněn tělesy a prázdnem rozličných tvarů, mohl by být jednotou leda akcidentálně. Neustále by se totiž kontinuálně proměňoval spolu s proměnami svých částí, jež by byly postupně zničeny a vytlačeny jinými. ${ }^{42}$ Již v rámci De origine rerum z roku 1676 však dospěl $\mathrm{k}$ závěru, že modifikace immensa $\mathrm{v}$ prostoru přesto nevyvolávají žádnou změnu, nýbrž jen přídavek čehosi dalšího, konkrétně hmoty (molis, massa), čímž vzniká konkrétní prostor, místa i intervaly v rámci něj, jejichž agregáty posléze dávají vzniknout prostoru univerzálnímu, kontinuálně proměnlivému. ${ }^{43}$ Prostor tedy není dílem toho či onoho tělesa, ani nějaké konečné bytosti, ani nepřechází ze subjektu na subjekt, nýbrž je stále neměnnou immensitou jediného a téhož immensa.

V době svého pařížského pobytu ${ }^{44}$ tak podle Arthura Leibniz považoval prostor i samotná místa za modifikace immensa vznikající bez-

38 Meditationes de Cognitione, Veritate et Ideis (Gottrried Wilhelm Leibniz, GP IV,426). Oproti tomu podle Clarka barvy, zvuky, chuti a podobná rozhodně nejsou účinky vyrůstajícími na základě pouhého tvaru a pohybu. Jedná se totiž podle něj naopak o myšlenky či modifikace mysli samotné, nejsou tedy přísně vzato vtištěním tvaru ani pohybu zapříčiněny (caused), nýbrž pouze podmíněny (occasioned) (A Demonstration of the Being and Attributes of God; Samuel Clarke, WC II,545).

39 Dopis Bernoullimu z 18. 11. 1698 (Gottrried Wilhelm Leibniz, GM III,552); Dopis de Volderovi ze 21. 1. 1704 (GotTfried Wilhelm Leibniz, GP II,262).

40 Dopis z 18. 11. 1708 (GottFried Wilhelm Leibniz, GLW 103).

41 De Origine Rerum ex Formis (Gottrried Wilhelm Leibniz, DSR 80).

42 Notizen zur Wissenschaft und Metaphysik (Gottrried Wilhelm Leibniz, A VI,3,391, §12-15).

43 De origine rerum ex formis (GottrRied Wilhelm Leibniz, A VI,3, 519,\$21-24).

44 Do Pařiže dorazil Leibniz v březnu 1672 a odjížděl z ní v říjnu 1676 (Nicholas JolleY, The Cambridge Companion to Leibniz, Cambridge: Cambridge University Press, 1995, s. 120, pozn. 29). 
prostředně na základě přidání hmoty. ${ }^{45}$ Agregát takovýchto míst posléze dává vzniknout univerzálnímu prostoru podobnému síti, jenž kontinuálně přijímá rozličné formy, a tudíž podléhá neustálé změně. Tím, co tedy v průběhu všech těchto změn přetrvává, je samotné immensum neboli Bůh, jenž je všudypř́tomný. Oproti tomu v rámci pozdějího De tempore (zřejmě z roku 1686) však uvedl, že k reálnému neměnnému prostoru se bezprostředně připojuje nikoliv hmota, nýbrž žádostivost, jež teprve dává vzniknout hmotě čili agregátu nekonečna jednotek. Jakmile se totiž $\mathrm{k}$ prostoru či rozprostraněnosti přidá žádostivost (appetite) či úsilí (endeavour), a v důsledku toho rovněž činnost, vyvstává konečně něco substanciálního, čímž není nic jiného nežli Bůh čili primární jednota. ${ }^{46}$ Variace pozice tak podle tohoto textu sice vskutku, v souladu s tvrzením z Dissertatio de arte combinatoria, vedou do komplexů automatic$\mathrm{ky}_{,}{ }^{47}$ ovšem nikoliv čistě na základě samotné kombinace forem v Bohu, nýbrž, jak ovšem Leibniz objasnil již o deset let dřive v rámci De formis simplicibus, za pouhého přispění (Božského) subjektu.

Samotný subjekt čili Bůh totiž poskytuje skrze svou všudypř́tomnost nesmírné, a právě toto nesmírné v kombinaci s jinými subjekty zajištuje, že následně vznikají veškeré možné mody čili tělesa samotná. $\mathrm{O}$ tom, že mody v subjektu vznikají jedině zásluhou nějakého jiného subjektu, byl ostatně přesvědčen také Clarke. ${ }^{48}$ Rozličné výsledky forem v kombinaci se subjektem tak dávají vzniknout výsledným jednotlivinám, ${ }^{49}$ reálný prostor samotný tím však zůstává nepoznamenán, zůstává totiž nedělitelný a neměnný..$^{50} \mathrm{~V}$ obou př́padech se tedy reálný prostor podobá prvotní látce, nebot je zbaven jakékoliv formy, rozdíl mezi pařížským De origine rerum a hannoverským De tempore nicméně podle Arthura spočivá $\mathrm{v}$ tom, že na druhém $\mathrm{z}$ nich už se odráží Leibnizova rehabilitace substanciálních forem. ${ }^{51}$ Vzhledem $\mathrm{k}$ tomu, že se však pravděpodobná datace De origine rerum shoduje s datací De formis simplicibus (Parkinson

„In Paris the spaces, places and intervals are modifications or modes of the immensum that result from the addition of mass directly." Richard ArTHuR, "Leibniz's Theory of Space," Foundations of Science 18, č. 3 [507] (2013): 499-528.

46 De tempore locoque, duratione ac spatio (GotTfried Wilhelm Leibniz, A VI,4,1641).

47 Dissertatio de Arte combinatoria (GotTfried Wilhelm Leibniz, GM V,40,§ 59).

48 A Defence of the Immateriality and Natural Immortality of the Soul (SAMUel CLARKe, WC III,760).

49 De formis simplicibus (GotTfried Wilhelm LeIbniz, DSR 84n.).

50 De tempore locoque, duratione ac spatio (Gottfried Wilhelm Leibniz, A VI,4,1641).

51 Arthur, „Leibniz's Theory of Space," Foundations of Science 18, č. 3 [508] (2013): 499-528. 
uvádí v obou případech duben 1676), stává se diskutabilním, zda lze Arthurův soud ohledně Leibnizových pařížských názorů považovat za podložený. Skutečnost, že se zde Leibniz o substanciálních formách nezmínil explicitně, zkrátka ještě nemusí znamenat, že by zde jejich podíl popíral, tím spíše, že v rámci De formis simplicibus z téhož období jej explicitně přiznal.

At̉ tak či tak, na základě uvedeného je patrné, že za svého mládí měl Leibniz ke ztotožnění prostoru s Boží immensitou poměrně blízko. ${ }^{52}$ Ještě počátkem roku 1679 ztotožňoval rozprostraněnost dokonce výhradně $s$ immensitou Boží a od tohoto pojetí podle Risiho neupustil ani později, i nadále totiž rozlišoval mezi proměnlivým prostorem a jeho neměnnou bází, totiž rozprostraněným per se neboli immensem, jež sice vykazuje mody, nikoli však části. ${ }^{53}$ Vzhledem $\mathrm{k}$ tomu, že navíc Leibnize ono ztotožňování prostoru s (Risim v tomto př́ípadě poněkud zkomolenou) ${ }^{54}$ immensitou neomrzelo dokonce ještě ani v rámci Specimen Dynamicum z roku $1695,{ }^{55}$ nemohu zkrátka souhlasit s Russellem, že, kdyby se Leibniz byl býval stal raději kritikem nežli komentátorem common sensu, mohl objevit nějakou mnohem uspokojivější teorii prostoru než tu, která sice vychází z commonsensového uznání jeho reality, fakticky však vede $\mathrm{k}$ jejímu úplnému popření. ${ }^{56}$

\section{2. (Pseudo)spor s Clarkem}

Jak již bylo naznačeno, Leibnizovo pojetí immensity se v tomto ohledu s Clarkovým, potažmo Newtonovým, nijak zásadně nerozchází. Leibnizovo zakotvení prostoru v immensitě Boží má totiž svůj protějšek v Newtonově formulaci z De gravitatione, že prostor je emanačním účinkem

52 De Risi, Geometry and Monadology, s. 565, pozn. 86.

53 Tamtéž, s. 69, vč. pozn. 74.

54 immensisteme (tamtéž, s. 565, pozn. 86).

55 Specimen dynamicum (GotTfried Wilhelm Leibniz, GM VI,2,247).

56 „It is a pity that Leibniz did not (...) make himself the critic rather than the commentator of common sense. Had he done so, he might have invented some more satisfactory theory of space than one which, while based upon a common-sense assumption of its reality, arrives, on that very basis, at a complete denial of that reality" (Bertrand Russell, A Critical Exposition to the Philosophy of Leibniz: With an Appendix with Leading Passages, Cambridge: Cambridge university Press, 1900, s. 74, § 33). 
věčného a neměnného jsoucna, ${ }^{57}$ stejně jako v Clarkově třetí odpovědi, že prostor je vlastností či důsledkem existence jsoucna nekonečného a věčného. ${ }^{58}$ Zatímco tedy Newton jej považoval za (Bohem stvořený) účinek, Clarke jej považoval za Boží vlastnost. Vždyt̉ jediným, co na tomto pojetí Clarke v rámci třetího dopisu odmítal, bylo Leibnizovo ztotožnění immensity s Bohem, ${ }^{59}$ jako to podle Jolleyho ${ }^{60}$ učinil rovněž Newton sám v Obecném scholiu druhé edice Principií z roku $1713 .{ }^{61}$ Prostor totiž podle Clarka rozhodně není (nekonečným a věčným) jsoucnem, nýbrž vlast-

57 „A odtud vyplývá, že prostor je emanativním účinkem prvotně existujícího jsoucna, nebot při umístění jakéhokoliv jsoucna je kladen prostor.“ [„Et hinc sequitur quod spatium sit entis primario existentis effectus emanativus, quia posito quolibet ente ponitur spatium" (De gravitatione; IsaAc Newton, U 103,136,\$4; srov. též IsaAc NewTON, U 99,132)]. Emanativním účinkem je konkrétně u Mora myšlen takový, jenž je zapř́činěn jsoucnem samotným, bez jakékoliv prostředkující činnosti či kauzality (Henry More, MA 32), čímž se vysvětluje Newtonovo prohlášení z De Gravitatione, že rozprostraněnost nebyla stvořena (creatura), nýbrž existuje věčně (De gravitatione; IsaAc Newton, U 109;143). Věčný a nekonečný prostor je totiž dle obou myslitelů emanativním účinkem Jsoucna věčného a nekonečného. Edward SLowick, „Newton Metaphysics of Space: A Tertium Quid betwix Substantivalism and Relationism, or Merely a God of the (Rational Mechanical) Gaps?," Perspectives on Science 17, č. 4 [438] (2009): 429-456.

„Prostor není jsoucnem, věčným a nekonečným jsoucnem, nýbrž vlastností či důsledkem existence jsoucna nekonečného a věčného. Nekonečný prostor je nesmírností: nesmírnost však není Bohem, nekonečný prostor tudíž není Bohem.“ [„,Space is not a being, an eternal and infinite being, but a property, or a consequence of the existence of a being infinite and eternal. Infinite space, is immensity: but immensity is not God: and therefore infinite space, is not God" (SAmuel Clarke, LC C.3.3)]. Srov. též: Clarkova odpověd' na pátý dopis pána z Gloucestershiru z 8. 4. 1713 (Samuel Clarke, WC II,750).

59 Dřive se ostatně Leibniz k takovému ztotožnění vskutku uchýlil: „Samotným immensem je však Bůh (...).“ [„Ipsum autem immensum est Deus (...)“ (De origine rerum ex formis; GotTfried Wilhelm Leibniz, DRS 78n.)].

60 Jolley, The Cambridge Companion to Leibniz, s. 302.

61 Newton zde údajně prostor ztotožnil nejprve s immensitou, a posléze s Bohem samotným: „Přetrvává navěky a je všude přítomen, a právě svou existencí vždy a všude ustanovuje trvání i prostor. (...) Všudypř́ítomným je nejen na základě své schopnosti, ale také substance, nebot' schopnost nemůže subsistovat bez substance. Je v něm zahrnuto a pohybováno veškerenstvo.“ [„Durat semper, \& adest ubique, \& existendo semper \& ubique durationem \& spatium constituit. (...) Omnipraesens est non per virtutem solam, sed etiam per substantiam: nam virtus sine substantia subsistere non potest. In ipso continentur \& moventur universa (...)“ (IsaAc Newton, PM III,528,obecné schol.)]. Samotný pojem immensitas se nicméně ve skutečnosti v rámci obecného scholia vyskytl výhradně v souvislosti s gravitací (IsAac Newton, PM II,527;530,obecné schol.), aniž by zde byl jakkoliv definován či vysvětlován. 
ností či důsledkem existence jsoucna nekonečného a věčného, ${ }^{62}$ což ovšem doslovně odpovídá někdejšímu Leibnizovu vlastnímu pojetí:

$\mathrm{V}$ prostoru však existuje cosi, co zůstává v průběhu změn, a to je vskutku věčné. Nejedná se o nic jiného nežli samotnou immensitu Boží, zajisté atribut (attributum), jenž je jediný, nedělitelný a současně nesmírný. Prostor je pouhým důsledkem (consequentia) tohoto, jako vlastnost (ut proprietas) esence. ${ }^{63}$

Coby př́klad Božího atributu je nesmírnost uvedena rovněž v rámci Specimen dynamicum ${ }^{64}$ a ve stejném duchu se následně nesla ještě dokonce i pasáž ze čtvrtého dopisu Clarkovi: „Je-li prostor absolutní skutečností, dalek toho být vlastností či akcidentem $\mathrm{v}$ protikladu $\mathrm{k}$ substanci, byl by více subsistující nežli samotné substance (...), ${ }^{\prime \prime 65}$ což Leibniz nadále už jen usvědčoval z absurdity, čímž de facto potvrdil, že vlastností či akcidentem být musí. Kromě rozprostraněnosti per se byla navíc Leibnizem za Boží atribut označena rovněž percepce per se. ${ }^{66}$

Dodejme, že atribut byl pro Leibnize takřka synonymem vlastnosti ${ }^{67}$ a že stejně tomu bylo rovněž $\mathrm{v}$ př́ípadě Clarka. I on totiž prostor příležitostně označoval prŕmo za atribut, ${ }^{68}$ jak je patrné dokonce ještě i z francouzského, Clarkem revidovaného překladu clarkovské korespon-

62 Samuel Clarke, LC C.3.3.

63 „Sed est aliquid in spatio, quod manet inter mutationes, id vero aeternum est, neque aliud est, quam ipsa immensitas Dei, attributum scilicet unum atque indivisibile simul et immensum. Cuius spatium est consequentia tantum, ut proprietas Essentiae" (Notizen zur Wissenschaft und Metaphysik; GotTrRied Wilhelm Leibniz, A VI,3,391,§15-18).

„Prostor, čas i pohyb mají cosi ze jsoucna rozumového, nikoliv samy od sebe, nýbrž do té míry, do jaké zahrnují Božské atributy: nesmírnost, věčnost, působnost či sílu stvořených substancí, jsou vskutku reálné.“ [„,(..) Spatium, tempus et motum habere aliquid de Ente rationis, nec per se sed quatenus Divina attributa, immensitatem, aeternitatem, operationem aut substantiarum creatarum vim involvunt, vera et realia esse" (Specimen dynamicum; GotTfried Wilhelm Leibniz, GM VI,2,247).

65 „Si l'espace est une realité absolue, bien loin d'etre une proprieté ou accidentalité opposée à la substance, il sera plus subsistant que les substances (...)“" (GotTFried WiLHELM LeibNiz, LC L.4.10).

66 De formis seu attributis Dei (GotTfried WiLheLm Leibniz, DSR 68n.).

67 Souhrn atributů nazýval Leibniz afekcí a afekci zahrnující veškeré atributy nazýval vlastností (Quod Ens perfectissimum sit possible; GotTfried WiLHeLm Leibniz, DSR 94n.). Srov. A Demonstration of the Being and Attributes of God (SAmuel Clarke, WC II,527-530). 
dence (sic!), ${ }^{69}$ př́padně za ,atribut nebo vlastnost ${ }^{\prime}{ }^{70}$ Důvod, proč přesto v rámci původní verze dopisů Leibnizovi trval výhradně na pojmu vlastnost, namísto poněkud přiléhavějšího pojmu atribut, však podle Koyrého spočívá konkrétně v Clarkově averzi vůči panteismu. Leibniz totiž v Clarkovi prostřednictvím devátého odstavce svého druhého dopisu zřejmě vyvolal obavu v souvislosti se Spinozou, pročež se Clarke veškeré panteistické terminologie raději vystř́ihal. Newton sám se přitom sice o Spinozovi nikde nezmínil, a pravděpodobně jej nikdy ani nečetl, jeho přátelé včetně Mora, Boyla i Clarka samotného už však Spinozu napadali zcela otevřeně. ${ }^{71}$

Spinoza ovšem zdaleka nebyl jediným, u koho se pojem atribut vyskytoval. Téhož pojmu totiž kromě Spinozy a Leibnize užíval mimo jiné rovněž Henry More, z něhož přitom do značné míry vycházel právě Newton. ${ }^{72}$ Snad právě proto se tedy Newton sám nezdráhal označit prostor explicitně nejen, v souladu s Clarkem, za důsledek nesmírného jsoucna, ale také, v souladu s Leibnizem, prŕmo za jeho atribut:

(...) Prostor je emanativním účinkem prvotně existujícího jsoucna (...). A totéž lze potvrdit ohledně trvání: obé je zajisté afekcemi jsoucna čili atributy (...). (...) Prostor je (...) emanativním účinkem věčného a neměnného jsoucna. ${ }^{73}$

Vzhledem k uvedenému tudíž nemohu souhlasit s Risim, podle něhož se Leibniz explicitního označení prostoru za atribut Boží vyvaroval, jako

69 A collection of pappers, which passed between the late Learned Mr. Leibnitz and Dr. Clarke (Samuel Clarke, WC IV,623).

70 Dopis od Clarka ze 28. 11. 1713 (Samuel Clarke, WC II,743); A Demonstration of the Being and Attributes of God (SAMUEL CLARKE, WC II,527-530).

71 Alexandre Koyré, From the Closed World to the Infinite Universe, Baltimore: The Johns Hopkins Press, 1957, s. 302, pozn. 15; Geoffrey Gorham, „Newton on God's Relation to Space and Time: The Cartesian Framework," Archiv für Geschichte der Philosophie 93, č. 3 [295, 304] (2011): 280-320. Srov. napr.. A demonstration of the Being and Attributes of God (Samuel Clarke, WC II,532;550;552;560); A Discourse concerning the Unchangeable Obligations of Natural Religion (Samuel Clarke, WC II,585); Clarkova odpovéd' na Sedmý dopis pána z Gloucestershiru (SAmuel ClaRKe, WC II,755).

72 Gorham, „Newton on God's Relation to Space and Time: The Cartesian Framework,“ s. 280-320.

$73 \ldots$, (...) Spatium sit entis primario existentis effectus emanativus (...). Deque Duratione similia possunt affirmari: scilicet ambae sunt entis affectiones sive attributa (...). (...) Spatium est (...) aeternis et immutabilis entis effectus emanativus" (De gravitatione; IsaAc Newton, U 103n.;136n.,\$4,6). 
se toho podle něj neodvážili ani Newton, a ani Clarke, tréebaže nakonec dospěli k podobnému závěru všichni tři. ${ }^{74}$

Ke ztotožnění Boha s místem či rovnou immensem se ostatně uchýlil už nejeden z církevních Otců, stejně jako po jejich vzoru ještě i mnozí teologové středověcí. Mezi tezemi zakázanými roku 1277 pařížským biskupem Tempierem se totiž nacházela mimo jiné i ta, že se andělé vyskytují v prostoru, či že jsou zde umístěni pouze na základě svého působení ${ }^{75}$ Mnoho autorů tudíž pod vlivem onoho odsouzení označilo vztah k fyzikálnímu místu za nutnou interní podmínku veškerých stvořených bytostí, jak materiálních, tak i duchovních, ${ }^{76} \mathrm{v}$ jejich prípadě se ovšem pochopitelně zatím ještě jednalo o místo ve smyslu klasicky aristotelském, tj. nekvantifikovaném. Oproti tomu všichni Patriziho následovnící ze 17. století, tj. nejen Leibniz, ale také More a v jeho stopách posléze rovněž Newton spolu s Clarkem, už však museli čelit podežrení, že mají tendenci učinit Boha rovnou kvantifikovaným, a snad i dělitelným, ${ }^{77}$ což jim ovšem na druhou stranu podle mého názoru nezabránilo takové riziko přesto podstoupit.

Tím spíše tedy nesouhlasím ani s tvrzením Vailatiho, podle něhož se Clarke s Leibnizem neshodli nejen na povaze, ale ani na ontologickém statusu času a prostoru. Není zkrátka pravdou, že, zatímco se podle Clarka jednalo o nutně existující Boží vlastnost, Leibniz jej považoval za pouhé relační ens rationis. ${ }^{78}$ Vailati, stejně jako ani Risi, se nicméně rozhodně nemýlí v tom, že Clarke skutečně souhlasil s označením nekonečného prostoru za nesmírnost, avšak s výhradou, že nesmírnost není Bohem, a tudíž není Bohem ani nekonečný prostor. Vzhledem $k$ výše i níže citovanému je ovšem krajně diskutabilním, zda to, co Clarke těmito slovy podsouval naopak Leibnizovi, Leibniz vůbec zastával. I on totiž v rámci

74 „Leibniz, true enough, refrains from maintaining explicitly that space is a divine attribute, but just because he does not dare to state what not even Newton or Clarke, though being in later years on not very different stances, will ever dare" (De RISI, Geometry and Monadology, s. 56).

75 Opiniones ducentae undeviginti Sigeri de Brabantia, Boetä de Dacia aliorumque (Étienne Tempier, CUP I,554,§204; 556,\$219).

76 Tiziana Suarez-NANI, „,Space and Mouvement in Medieval Thought: The Angelological Shift," in Space, Imagination and Cosmos from Antiquity to the Early Modern Period, ed. Frederik Bakker - Delphine Bellis - Carla Rita Palmerino, Cham: Springer, 2019, s. 74n.

77 Vincenzo De RIsI, „Francesco Patrizi and the New Geometry of Space," in Boundaries, Extents and Circulations: Space and Spatiality in Early Modern Natural Philosophy, ed. Koen Vermeir - Jonathan Regier, Cham: Springer, 2016, s. 72.

78 Vailati, Leibniz and Clarke, s. 136n. 
třetího dopisu Clarkovi ztotožnění prostoru s Bohem odmítl a současně tentokrát vskutku odmítl dokonce už i označení prostoru za Boží atribut zvaný nesmírnost, jak správně avizoval Risi:

Jsou tací, kteří věřili, že by se jednalo o Boha samotného či spiše o jeho atribut, o jeho nesmírnost. Jelikož však [prostor] sestává z částí, o nic, co by mohlo konvenovat s Bohem, se nejedná. ${ }^{79}$

V rámci immensa totiž nelze identifikovat žádná aktuální, ale ani potenciální místa vůbec. Immensum je neporušené, zbavené jakýchkoli určení, a v důsledku toho nikoliv aktuálně existující. Představuje-li zkrátka nekonečný prostor immensitu, konečný prostor bude vyloženě jejím opakem, tedy prostorem měřitelným (mensurabilité) či omezenou rozprostraněností. ${ }^{80}$ Ve stejném duchu proto Leibniz své odmítnutí doslovného ztotožnění prostoru s immensitou potvrdil posléze ještě i v rámci pátého dopisu ${ }^{81}$ kde kromě toho znovu explicitně odmítl rovněž označení prostoru za Boha či Boží vlastnost, ${ }^{82}$ jaké přitom Clarke ve třetím dopise vyčítal na oplátku zase jemu. ${ }^{83}$ „,(..) Tvrzením, že prostor je Boží vlastností,“ se však, trval Leibniz na svém, právě Clarke „přiblížil k tomu, aby se této obtíži vyhnul. Na to jsem ve svém předchozím dopise kontroval, že

79 „(...) Il y en a qui ont crû que c'estoit Dieu luy même, ou bien son attribut, son immensité. Mais comme il a des parties, ce n'est pas une chose qui puisse convenir à Dieu" (GotTfried Wilhelm Leibniz, LC L.3.3).

80 „Si l'espace enfini est l'immensité, l'espace fini sera l'opposé de l'immensité, c'est à dire, la mensurabilité, ou l'étendue bornée“" (GotTfried Wilhelm Leibniz LC L.4.9n.).

81 „Prostor není (§ 39) afekcí jednoho tělesa či jiného, či libovolného konečného jsoucna, ani nepřechází ze subjektu na subjekt, nýbrž vždy je konstantně nesmírností jednoho jediného a stále téhož nesmírna." [,,Space is not an (§ 39) affection of one body, or of another body, or of any finite being; nor passes from subject to subject; but is always invariably the immensity of one only and always the same immensum" (SAMUEL ClarKE, LC C.5.36-48)].

82, „(..) Onen úskok, že prostor a čas jsou v Bohu a jakoby Božími vlastnostmi, je již uzavřen." [„,(..) L'échappatoire que l'Espace et le Temps sont en Dieu, et comme des proprietés de Dieu, est déja fermé" (GotTfried Wilhelm Leibniz LC L.5.50)].

83 „Prostor není jsoucnem, věčným a nekonečným jsoucnem, nýbrž vlastností či důsledkem existence jsoucna nekonečného a věčného. Nekonečný prostor je nesmírností: nesmírnost však není Bohem, nekonečný prostor tudíž není Bohem.“ [„,Space is not a being, an eternal and infinite being, but a property, or a consequence of the existence of a being infinite and eternal. Infinite space, is immensity: but immensity is not God: and therefore infinite space, is not God" (SAmuel Clarke, LC C.3.3)]. 
vlastností Boží je nesmírnost, prostor (jenž je mnohdy poměřován s tělesy) a nesmírnost Boží však nejsou tímtéž. " 84

Reálný prostor, tj. immensum, byl tedy podle Leibnize něčím jediným, nedělitelným a neměnným, což ovšem i v tomto případě přesně odpovídá Clarkovu předpokladu, že nekonečný prostor představuje immensitu, jež je jediná, absolutně a esenciálně nedělitelná:

Ani v tom, co je zde tvrzeno ohledně prostoru obsahujícího části, není žádná obtíž. Nekonečný prostor je totiž jeden, absolutně a bytostně nedělitelný, takže předpoklad jeho členitosti je předpokladem vnitřně rozporným, nebot by musel existovat prostor rovněž v jednotlivých článcích samotných, což by si opět vyžádalo předpoklad jejich členitosti, ale i nečlenitosti zároveň. ${ }^{85}$

Vzhledem k tomu, že za věčně trvající a svou povahou neměnný označil prostor také Newton, ${ }^{86}$ lze navíc dodat, že dokonce i prostor Newtonovy fyziky spolu s prostorem leibnizovským sdílel veškeré vlastnosti eukleidovského prostoru: jeho struktura byla konstantní, na čase nezávislá. S jistotou se jednalo o prostor neohraničený a nekonečný, ${ }^{87}$ kdyby však měly být vskutku identické, pak by se ani v Newtonově případě rozhodně nemohlo jednat o prostor dělitelný, a už vůbec ne neomezeně dělitelný, jak jej přitom interpretují Čapek, ${ }^{88}$ Khamara $^{89}$ či Jacquette..$^{90}$

84, „(...) On a teché d'eluder cette difficulté, en disant que l'espace est une proprieté de Dieu. J'ay opposé à cela dans mon papier precedent, que la proprieté de Dieu est l'immensité; mais que l'espace, qui est souvent commensuré avec les corps, et l'immensité de Dieu n'est pas la même chose" (Gottrried Wilhelm Leibniz, LC L.5.36).

85 „Nor is there any difficulty in what is here alleged about space having parts. For infinite space is one, absolutely and essentially indivisible: and to suppose it parted, is a contradiction in terms; because there must be space in the partition itself; which is to suppose it parted, and yet not parted at the same time" (SAMUEL CLARKE, LC C.3.3).

$86, \ldots(\ldots)$ Prostor je co do trvání věčný a co do své povahy neměnný $(. ..) . “\left[{ }^{\prime \prime}(\ldots)\right.$ Spatium est aeternae durationis et immutabilis naturae (...)" (De gravitatione; IsaAc Newton, U $104 ; 137, \S 4,6)]$.

87 V rámci De Gravitatione Newton uvedl, že prostor je nekonečně rozprostraněný ve všech směrech. Žádnou hranici si totiž nelze představit bez souběžné představy prostoru za ní. I nekonečná rozprostraněnost je sice rovněž nepředstavitelná, lze jí však alespoň porozumět (De gravitatione; IsaAc Newton, U 101;133,\$2).

88 „Prostor Newtonovy fyziky měl všechny vlastnosti prostoru Eukleidova (...). Je bez hranic, nekonečný, kontinuitní, tj. neomezeně dělitelný.“ Milič ČAPEK, „Odklon od klasického determinismu vlivem filosofie a fyziky dvacátého století a rehabilitace principu mravní svobody," Reflexe, č. 18 [6] (1998): 1-14.

89 „Newton zastával prostor a čas coby aktuálně nekonečně dělitelná prostředí pro konečný počet atomů (...).“ [„,Newton championed space and time as actually infinitely 
Newton sám sice v rámci nevydaných rukopisů z let 1692-1693 explicitně odmítl, že by prostor měl být složen z částí, přesto jej však podle Koyrého za nedělitelný neoznačil nijak explicitně, ${ }^{91}$ ba, v rámci Optiky jej dokonce explicitně označil naopak za nekonečně dělitelný. Tvrzením, že se nerozkládá do částí, měl totiž na mysli pouze, že se místo toho rozkládá do bodů, jež jsou přitom co do velikosti ničím..$^{92}$ Že „,(...) je hypotéza nedělitelných ,tvrdým ořiškem' (...), (...) pročež bych v následujícím neměl chtít nahlížet nedělitelné, nýbrž zdánlivě nedělitelné (...)," se ostatně dozvídáme rovněž z Principiú. ${ }^{93} \mathrm{O}$ tom, že konečné nemůže být součástí nekonečného, nýbrž má se vưči němu jako matematické body vưči kvantitě, byl navíc posléze přesvědčen rovněž Clarke a také on v důsledku toho veškerou kvantitu označil za nekonečně dělitelnou. ${ }^{94}$

Newtonovo, stejně jako Clarkovo ztotožnění nekonečně dělitelného prostoru s Bohem je tudíž samo o sobě rozporné, což je jedním z hlavních důvodů, proč se vưči němu Leibniz v rámci clarkovské korespondence vymezoval.

$\mathrm{V}$ prvé řadě by tedy podle Leibnize prostor nemohl být totožný s Bohem právě proto, že obsahuje aktuální části, jimiž by tudíž musel být obdařen rovněž Bưh sám, ${ }^{95}$ nebot dělitelnost prostoru by svou dělitelností kontaminovala dokonce i jeho, ${ }^{96}$ a nestačilo by ani, že se jedná o části neoddělitelné (takto totiž Leibniz př́ležitostně vymezoval prosto-

divisible receptacles for a finite number of atoms (...)" (Edward Khamara, Space, Time and Theology in the Leibniz-Newton Controversy, Frankfurt: Ontos Verlag, 2006, s. II)].

90 ,(...) Newtonův fyzikální prostor je eukleidovský, přinejmenším v analogickém smyslu, přímočarý a nekonečný co do rozsahu i matematické dělitelnosti." [„,(..) For Newton physical space is Euclidean, at least in an analogical sense, rectilinear, and infinite in extent and mathematical subdivisibility" (Dale JACQuETTE, "Newton's Metaphysics of Space as God's Emanative Effect," Physics in Perspective 16, č. 3 [348] (2014): 344-370)].

91 Alexandre Koyré, From the Closed World to the Infinite Universe, Baltimore: The Johns Hopkins Press, 1957, s. 165.

92 James McGuire, „Newton on Place, Time, and God: An Unpublished Source,“ British Journal for the History of Science, č. 11 [116] (1978): 114-129.

93 ,(...) Durior est indivisibilium hypothesis (...). (...) Proinde in sequentibus (...) nolim indivisibilia, sed evanescentia divisibilia (...) semper intelligi“ (IsAAC NEwTON, PM $\mathrm{I}, 37, \S 1)$.

94 A Demonstration of the Being and Attributes of God (SAmuel Clarke, WC II,525).

95 Gottriend Wilhelm Leibniz, LC L.5.42.

96 Samuel Clarke, LC C.5.51. Srov. též Theophil v Nouveaux essais (Gottrried Wilhelm LeIBNIZ, GP V,136,XIII,§17). 
rové body). ${ }^{97}$ Clarke sice původ této námitky vystopoval již u scholastiků, ${ }^{98}$ ti se s ní ovšem ještě, vzhledem k tomu, co bylo uvedeno ohledně Tempierových tezí, př́liš ztotožňovat nemohli. Má-li být nicméně nekonečný prostor Boží immensitou, pokračoval Leibniz, nekonečný čas bude Boží věčností, takže vše, co se nachází v prostoru a čase, bude současně v immensitě Boží. ${ }^{99}$ Prostory však bývají jednou prázdné, jindy naplněné (existenci vakua přitom Leibniz zásadně odmítal). ${ }^{100}$ Též Boží esence by tak musela obsahovat části někdy prázdné, jindy plné, a v důsledku toho náchylné $\mathrm{k}$ neustálé změně. ${ }^{101}$ Fakticky přitom nesmírnost ani všudypř́tomnost Boží nerozděluje jeho substanci na jednotlivé části o nic více, než trvání či kontinuita rozděluje na jednotlivé části jeho existenci, ${ }^{102}$ což přitom v rámci dopisu pánovi z Gloucestershiru kvitoval rovněž Clarke. ${ }^{103}$

Dalším z důvodů, proč podle Leibnize „nekonečný prostor není Boží nesmírností (...), "'104 je ten, že kdyby byly totožné, nekonečnost prostoru by konkurovala nekonečné immensitě Boží a věčnost času by zase konkurovala Boží věčnosti. ${ }^{105}$ Kdyby navíc měla být realita prostoru i času pro jeho nesmírnost a věčnost nezbytná, dodal, kdyby se musel nacházet

97 Srov. Theoria motus abstracti (GotTfried Wilhelm Leibniz, GP IV,229,§5); Dopis Arnauldovi z listopadu 1671 (GotTfried WiLhelm, GP I,72), ale též Initia rerum mathematicarum metaphysica (GotTfried Wilhelm, GM VII,18). Č́sti ostatně bodům, nedílným místům i duchům přiznával už Suárez (Francisco SuÁrez, DM 51,1:10;3:3n.).

98 Odpověd' na šestý dopis pána z Gloucestershiru (SAmuel Clarke, WC II,753).

99 GotTfried Wilhelm Leibniz, LC L.5.44.

100 Gottfried Wilhelm Leibniz, LC L.5.127.

101 Gottrried Wilhelm Leibniz, LC L.5.43. Neméně problematický je předpoklad vakua rovněž $\mathrm{v}$ př́ípadě, že by byl prostor Boží vlastností. Rozprostraněnost jako taková by totiž musela být afekcí čehosi rozprostraněného. Kdyby však prostor měl být prázdný, jednalo by se o atribut bez subjektu, o rozprostraněnost bez čehokoliv rozprostraněného. Prostor tudíž nemůže být Boží vlastností (GotTfried Wilhelm Leibniz, LC L.4.9n.).

102 Samuel Clarke, LC C.3.3n.

103 Odpověd' na šestý dopis pána z Gloucestershiru (SAmuel Clarke, WC II,753).

104 „L'espace infini n'est pas l'immensité de Dieu (...)“ (Gottfried Wilhelm Leibniz, LC L.5.46).

105 Gottrried Wilhelm Leibniz, LC L.5.44. Př́mo Newtonovi tuto námitku přednesl namísto Leibnize Berkeley: absolutní prostor by podle něj bud’ musel být s Bohem vyloženě identický, nebo by mu alespoň musel zásadně konkurovat (A Treatise Concerning the Principles of Human Knowledge; GeORge BerKeLey, BT 173n.,I,§117). Obecné scholium se tak ve druhé edici Principií objevilo zvětšiny právě na popud Berkeleyho kritiky absolutního prostoru (a Leibnizovy kritiky gravitační teorie) (Martin, Leibniz's Conception of Analysis Situs and Its Relevance to the Problem of the Relationship between Mathematics and Philosophy, s. 187). 
$\mathrm{v}$ prostoru a kdyby toto bytí v prostoru mělo být jeho vlastností, byl by na prostoru a času do jisté míry závislý, ${ }^{106}$ nemohl by jej tudíž zničit, ani žádným způsobem pozměnit. Prostor jakožto celek by tedy byl nejen nesmírným, ale rovněž $\mathrm{v}$ každé ze svých částí nezničitelným a nezměnitelným. ${ }^{107}$ Fakticky by přitom nesmírnost i věčnost Boží přetrvávaly dokonce i tehdy, kdyby na světě nebylo ani jediné bytosti, nijak by ovšem podle Leibnize nezávisely na čase ani prostoru. Oproti tomu čas, prostor, a v důsledku toho ani žádný aktuální prostor už by však bez stvořených bytostí existovat nemohly..$^{108}$

Není tedy pravdou, že, jak tvrdí Vailati, Leibniz nepodal vysvětlení, zda by bylo možno klást prostor i tam, kde neexistuje žádné těleso. ${ }^{109}$ Vždyt prostor pro Leibnize $\mathrm{v}$ posledku nebyl ničím než souhrnem možných pozic, jaké mohou jednotlivé objekty vzájemně zaujímat. ${ }^{110}$ Kdyby tudíž tyto objekty neexistovaly, neexistoval by ani prostor. Nesmírnost, stejně jako věčnost, totiž v takovém př́ípadě kontrafaktuálně označuje pouze to, že Bůh by v opačném př́padě byl býval př́tomen a koexistoval by spolu se vším ostatním. Kdyby však existoval pouze Bůh, čas a prostor by se nacházely výhradně v něm coby pouhé možnosti, 111 jedná se totiž o záležitosti mnohem význačnější (éminent), než je trvání a rozprostraněnost konkrétních bytostí. ${ }^{112}$ Stále by sice, dodejme ještě, prostor vykazoval pozici a rovněž jistou mnohost, nikoli však rozprostraněnost. ${ }^{113}$

106 GotTfried Wilhelm Leibniz, LC L.5.50.

107 Kdyby měl prostor vykazovat absolutní realitu, přináležela by mu kromě toho rovněž větši míra reality než samotným substancím. Mimo Boha by tak existovalo nekonečno věčných entit (GotTfried Wilhelm Leibniz, LC L.4.9n.).

108 , (...) Nesmírnost ani věčnost Boží by nepřestaly subsistovat ani bez stvořených bytostí, postrádaly by však jakoukoliv závislost na časech či místech. Kdyby neexistovaly stvořené bytosti, neexistoval by ani čas, ani místo, a v důsledku toho ani žádný aktuální prostor.“ [„,(...) Sans les Creatures, l'immensité et l'Eternité de Dieu ne laisseroient pas de subsister, mais sans aucune dependance ny des temps ny des lieux. S'il n'y avoit point de creatures, il n'y auroit ny temps ny lieu; et par consequent point d'espace actuel“ (Gottfried Wilhelm Leibniz, LC L.5.106)].

109 Vailati, Leibniz and Clarke, s. 116.

$110, \ldots$ Cet ordre qui fait que les corps sont situables, et par lequel ils ont une situation entre eux en existant ensemble (...)" (Gottfried Wilhelm Leibniz, LC L.4.41)].

111 Abstraktní prostor je čímsi ideálním, co by při odstranění stvořeného neexistovalo jinak než v ideích Božích (Dopis Bernoullimu ze 7. 6. 1716; Gottrried Wilhelm Leibniz, GM III,964).

112 „Nesmírnost Boží je na prostoru nezávislá, podobně jako je Boží věčnost nezávislá na čase. Vzhledem $\mathrm{k}$ těmto dvěma řádům těles $\mathrm{s}$ sebou přináší pouze to, že Bůh by byl př́tomný a koexistující s veškerými tělesy, jež by měla existovat. Nepřijímám tak, co 
Bůh je tedy podle Leibnize skrze svou immensitu aktuálně přítomen ve veškerém prostoru, což potvrzoval rovněž Newton. Přestože totiž podle Newtona Bủh sám není trváním ani prostorem, přetrvává a je př́tomen. Přetrvává vždy a je př́tomen všude, a na základě existence vždy a všude ustanovuje trvání i prostor. Jelikož navíc $\mathrm{v}$ důsledku toho rovněž každičká částečka prostoru existuje vždy a každičký nedělitelný okamžik trvání spočivá všude, jistě se nikdy nestane, že by se tvůrce a pán veškerenstva nacházel nikdy či nikde. I v trvání samotném lze sice identifikovat sukcesivní části a v prostoru části koexistující, žádná $\mathrm{z}$ těchto se však nenachází v osobě člověka ani v principu jeho myšlení, a tím méně v myslící substanci Boží. ${ }^{14}$ Nachází-li se tedy Bủh v prostoru, kvitoval Newtonovo stanovisko Leibniz, jak by se mohl prostor nacházet $\mathrm{v}$ něm či jak by mohl být jeho vlastností? Vlastnost se sice jistě může nacházet ve svém subjektu, těžko by se však subjekt mohl nacházet ve své vlastnosti. Podobně, existuje-li Bůh v každém čase, jak by mohl čas existovat $\mathrm{v}$ něm, jak by mohl být jeho vlastností? ${ }^{115}$

Právě v této fázi, totiž po pokusu o vyvrácení veškerých Clarkových ,iluzí ohledně immensity a naprostém popření téže iluze, k níž se dokonce ještě i v rámci samotné korespondence s Clarkem sám hlásil, i u sebe sama, se však Leibnizův výklad na toto téma vyčerpává. Ohledně Leib-

je zde předkládáno, že kdyby existoval pouze Bůh, čas i prostor by existovaly stejně jako nyní. Namísto toho by tedy, dle mého názoru, nebyly ničím než pouhými idejemi, coby prosté možnosti. Nesmírnost i věčnost Boží jsou čímsi význačnějším než trvání a rozprostraněnost stvořených bytostí, nejen co do velikosti, ale také z povahy věci. Tyto božské atributy mimo Boha nevyžadují žádné záležitosti, jako jsou aktuální místa a časy, což jsou pravdy, jež byly dostatečně uznány jak teology, tak také filosofy.“ [„L'immensité de Dieu est independante de l'espace, comme l'éternité de Dieu est independante du Temps. Elles portent seulement à l'egard de ces deux ordres des choses, que Dieu seroit present et coexistant à toutes les choses qui existeroient. Ainsi je n'admets point ce qu' on avance icy, que si Dieu seul existoit, il y auroit temps et espace, comme à present. Au lieu qu'alors, à mon avis, ils ne seroient que dans les idées, comme les simples possibilités. L'immensité et l'éternité de Dieu sont quelque chose de plus eminent que la durée et l'étendue des creatures, non seulement par rapport à la grandeur, mais encore par rapport à la nature de la chose. Ces attributs Divins n'ont point besoin de choses hors de Dieu, comme sont les lieux et temps actuels. Ces verités ont eté assez reconnues par les Theologiens et par les Philosophes" (GotTfried Wilhelm Leibniz, LC L.5.106)]. Srov. též Dopis Bernoullimu ze 7. 6. 1716 (GotTfried WiLHELM LeIBNIZ, GM III,964).

113 De formis simplicibus (GotTfried Wilhelm Leibniz, DSR 82n.).

114 IsaAc Newton, PM 528, obecné schol.

115 Gottrried Wilhelm Leibniz, LC L.5.45. 
nizova vlastního pojetí se tak s jistotou dozvídáme pouze to, že nejen v rámci předchozích spisů, ale zřejmě dokonce ještě i v rámci čtvrtého dopisu Clarkovi takřka doslovně odpovídalo pojetí Clarkovu. Jaký výklad nesmírnosti však Leibniz sám doporučoval namísto něj, to už se zřejmě z clarkovské korespondence nikdy nedozvíme. Přece však situace ani $\mathrm{v}$ tomto ohledu není zcela beznadějná. Nenachází-li se totiž odpověd' v samotné Leibnizově korespondenci s Clarkem, jistě se bude nacházet někde jinde...

ZÁvĚR

Důvod, proč Leibniz v rámci korespondence s Clarkem přijímal definici prostoru coby modifikace immensa, a přitom odmítal, že by se mělo jednat o Boží atribut, vlastnost, či emanativní účinek, se stává patrným teprve se zřetelem na jeho definici př́slušných pojmů. Zatímco totiž Clarke, jehož dílo Leibniz četl, ${ }^{116}$ pojmů atribut, vlastnost, účinek a modus př́ležitostně užíval synonymně, ${ }^{117}$ Leibniz sám už oproti tomu mezi mody a ostatními typy predikátů zásadně rozlišoval.

Především je totiž podle něj zapotřebí rozlišovat mezi přetrvávajícími vlastnostmi či atributy a pouhými přechodnými modifikacemi. Zatímco tedy vlastnosti spolu s atributy jsou esenciální a věčné, modifikace se mohou proměňovat. ${ }^{118}$ I atributy jsou sice, podobně jako mody, rovněž zahrnuty v substanci, na rozdíl od modů jsou však pojímány skrze sebe sama, nikoliv skrze substanci. ${ }^{119}$ Kdybychom prritom mody definovali

116 Dopis od Karolíny Leibnizovi z 15./26. 11. 1715 (GottrRied Wilhelm Leibniz, K II,52). Není mi sice známo, jakéže Clarkovy spisy Leibniz přesně četl, mimo jiné se však mezi nimi nacházely dopisy Dowellovi, anonymnímu autorovi či Collinsovi (Dopis Karolíně z konce listopadu 1715; Gottrried Wilhelm Leibniz, K XI,60; Vailati, Leibniz and Clarke, s. 65), kde Clarke s těmito ontologickými kategoriemi skutečně nakládal poněkud synonymně.

117 Srov. A Demonstration of the Being and Attributes of God (Samuel Clarke, WC II,527-530); A Defence of the Immateriality and Natural Immortality of the Soul (SAmuel Clarke, WC III,759); Clarkiov dopis ze 28. 11. 1713 (Samuel Clarke, WC II,743); Clarkova odpovéd' na Třetí dopis pána z Gloucestershiru (SAMUEL CLARKE, WC II,745).

118 Nouveaux essais (Gottrried Wilhelm Leibniz, GP V,56); Dopis de Volderovi ze 31. 12. 1700 (Gottfried Wilhelm Leibniz, LDV 198n.), z 10. 11. 1703 (GotTfried Wilhelm Leibniz, GP II,258) a z 19. 11. 1703 (Gottrried Wilhelm Leibniz, LDV 279); Addition à l'Explication du systeme nouveau (GotTfried Wilhelm Leibniz, GP IV,582,§4).

119 Ad Ethicam B. d. Sp. (GotTfried Wilhelm Leibniz, GP I,139,I,def. 5). 
čistě skrze jejich závislost na jiném pojmu, pak by jistě bylo možno řadit mezi ně rovněž vlastnosti. Vždyt' obsaženost $\mathrm{v}$ něčem je typická jak pro mody, tak i pro vlastnosti. Stejně tak ovšem tatáž definice pasuje rovněž na záležitosti, jež v ničem zahrnuty nejsou, jako jsou účinky, jež ke svému porozumění vyžadují porozumění př́čině. Takto by se tudíž z veškerých účinků staly modifikace př́slušných příčin, takže by se tentýž účinek mohl stát modem hned několika př́ćčin najednou, ${ }^{120}$ stejně jako je tomu i v př́ipadě atributů, pro něž zkrátka pravidlo, že žádné dvě substance nemohou být dokonale podobné, neplatí. ${ }^{121}$

„Kdo by také popřel,“ tázal se Leibniz, „že substance je modifikována intervencí jiné, podobně jako je těleso odraženo přistrčenou překážkou? Pro rozlišené uchopení odrazu jednoho tedy bude zapotřebí pojmu obou těles, a přesto mưže být odraz modem výhradně jednoho, nastane-li, že druhé těleso pokračuje v cestě bez vychýlení. " ${ }^{122}$ Pro definici modifikace je tudíž zapotřebí něčeho víc než jen pouhého vyžadování druhého pojmu a rovněž ,zahrnutost $\mathrm{v}^{\prime}$ (charakteristika společná jak vlastnostem, tak i modům) musí v př́ípadě modů značit něco víc než jen pouhou potřebu čehosi dalšího. Na celém stvořeném světě ostatně neexistuje nic, co by pro svůj úplný pojem nepotřebovalo pojem všeho ostatního ve veškerenstvu, ${ }^{123}$ takže čistě na základě této skutečnosti modifikaci vysvětlit nelze. Nejenže tedy vzhledem k uvedenému nelze souhlasit s Vailatim, podle něhož Leibniz nepodal žádné vysvětlení, co že se mu na nemodálním pojetí inherence jeví být nepřijatelným. ${ }^{124}$ Především se tím totiž ujasnilo, že se $\mathrm{v}$ př́ípadě prostoru jedná o atribut proměnlivý, jaký navíc nelze pojímat skrze sebe sama, nýbrž jedině skrze substanci samotnou (tj. Boha).

120 Dopis de Volderovi ze 6. 7. 1701 (GottrRied Wilhelm Leibniz, LDV 208n.); De aequipollentia causae et effectus (Gottrried Wilhelm Leibniz, A VI,4,1963,§12n.). Proto je také Leibniz považoval za akcidenty absolutní, nikoliv modální [,Posteriores (...) sunt (...) accidentia absoluta (...)" (Poznámky k Temmnikově Philosophia vera; GotTfried Wilhelm Leibniz, MU 163, pozn. 87, 101)].

121 Gottrried Wilhelm Leibniz, LC L.5.47.

122 „Quis neget etiam aliquam substantiam alterius interventu modificari? Ut cum corpus reflectitur ob obstaculum oblatum. Utriusque igitur corporis conceptus ad reflexionem unius distincte concipiendam erit necessarius et tamen reflexio potest esse modus, non nisi unius, cum fieri queat ut alterum pergat, non reflectatur" (Dopis de Volderovi ze 6. 7. 1701; GotTfried Wilhelm Leibniz, GP II,226).

123 Dopis de Volderovi ze 6. 7. 1701 (Gottrried Wilhelm Leibniz, GP II,226)

124 Vailati, Leibniz and Clarke, s. 151. 
Konkrétně v rámci dopisu pánovi z Gloucestershiru ovšem i Clarke ve stejném duchu potvrdil, že dokonce ani nesmírnost samotnou nelze považovat za atribut ve stejném smyslu, jako je jím moudrost, síla a podobná, což navíc jinde upřesnil ještě tím, že do opozice vůči veškerým kvalitám tohoto typu postavil právě mody. Mody zde následně vymezil na základě jejich mnohem volnější vazby na subjekt samotný, což jim tudíž v porovnání s ostatními kvalitami typu atributů či vlastností přináší nesporné výhody. ${ }^{125}$ Atributy ani vlastnosti totiž především nelze predikovat sobě navzájem, zatímco nesmírnost je modem nejen Boží substance samotné, ale také veškerých jejích atributů. Podle Clarka se tak dokonce i v př́padě immensity samotné př́sně vzato jedná o pouhý modus, stejně jako je tomu v př́padě věčnosti, nebot i ta je trváním přisuzovaným jak Boží substanci samotné, tak také veškerým jejím atributům. Nesmírnost ani věčnost tedy podle něj př́sně vzato nelze považovat za atribut ani vlastnost, nýbrž za modus substance samotné včetně veškerých jejích atributů, ${ }^{126}$ což ovšem obecně uznával také Leibniz. I on byl totiž mody ochoten přisuzovat nejen substancím, ale také akcidentům. ${ }^{127}$

Jelikož se tedy $\mathrm{k}$ takto spinozovské terminologii přinejmenším po jistou dobu explicitně hlásil nejen Leibniz, ale také Clarke, nebot̉ i on prostor př́ležitostně označoval prrímo za modus, ${ }^{128}$ můžeme uzavřít, že ani jeden $\mathrm{z}$ nich vskutku ani $\mathrm{v}$ nejmenším nezamýšlel oddělit prostor od Boha. Vzhledem k tomu, že mody byly již u Suáreze, jehož dílo přitom

125 A Defence of the Immateriality and Natural Immortality of the Soul (SAmuel Clarke, WC III,760); A Second Defence of the Immateriality and Natural Immortality of the Soul (SAMUEL Clarke, WC III,785); A Third Defence of an Argument Made use of in a Letter to Mr. Dodwell (SAMUel Clarke, WC III,825). Vzhledem $\mathrm{k}$ tomu, že posléze už při téže klasifikaci v souvislosti s popisem skutečně inherujících kvalit jednou zcela opomíjel atributy i vlastnosti (A Defence of the Immateriality and Natural Immortality of the Soul; SAMUEL CLARKe, WC III,762), a jindy zase mody (A Second Defence of the Immateriality and Natural Immortality of the Soul; SAMUel Clarke, WC III,795), znovu se tím potvrzuje, že mody, atributy a vlastnosti pojímal takřka synonymně.

126 Clarkova odpovéd’ na sedmý dopis pána z Gloucestershiru (Samuel Clarke, WC II,758).

127 De mundo praesenti (GottrRied Wilhelm Leibniz, LoC 282n.); Ad Ethicam B. d. Sp. (GotTfRIed Wilhelm Leibniz, GP I,147,I,prop. 23); Předmluva k Marii Nizolii De Veris principiis; GotTfried Wilhelm Leibniz, GP IV,147).

128 Srov. znovu A Demonstration of the Being and Attributes of God (Samuel Clarke, WC II,527-530); A Defence of the Immateriality and Natural Immortality of the Soul (SAMUEL Clarke, WC III,759); Clarkũv dopis ze 28.11. 1713 (Samuel Clarke, WC II,743) či Clarkova odpověd' na Třetí dopis pána z Gloucestershiru (SAmuel Clarke, WC II,745). 
Leibniz dle vlastních slov četl jako román, ${ }^{129}$ definovány coby určení od př́slušných substancí reálně odlišná, ${ }^{130}$ stávají se navíc Leibnizovy záměry o to patrnějšími. Proměnlivý a dělitelný prostor coby modus se totiž vzhledem $\mathrm{k}$ tomu stává od neměnného a nedělitelného immensa skutečně odlišným, a přitom současně neoddělitelným, díky čemuž se Leibnizovi podařilo odstranit očividnou nekonzistenci v Newtonově pojetí.

\section{Immensum in the Context of Leibniz's Correspondence with Clarke}

Keywords: Leibniz; Newton; Clarke; Space; Immensum

Abstract: This study challenges some interpretative strategies comparing Leibniz's, or even Newton's metaphysics of space to a Cartesian one. Not only did both Newton and Leibniz explicitly oppose Cartesian metaphysics as such, but neither of them had even the slightest intention of separating space from God, although they did not agree on the exact nature of such a space-God relationship. Moreover, it was just a conceptual disagreement, since the identification of space with an attribute of God is to be found not only by Leibniz but also by Newton, as well as by his defender Samuel Clarke. Neither diverge the reasons why Leibniz no more than Clarke eventually argued for the category of modification rather than an attribute.

Mgr. Kateřina Lochmanová

Katedra filozofie

FF Ostravské univerzity

Reální 5, 70103 Ostrava

lochmanovakatka@gmail.com

129 „Suárez se mi četl se stejnou lehkostí, s jakou máme ve zvyku [číst] Mílétské povídky, jež lidé nazývají romány." [„,(..) Suaresium non minori facilitate legerem, qua Milesias fabulae solemus, quas vulgo Romanas vocant" (Autobiografie; GotTFried Wilhelm LeibNIZ, PG I,4,168)].

130 Francisco SuÁrez, DM 7,1:17. 